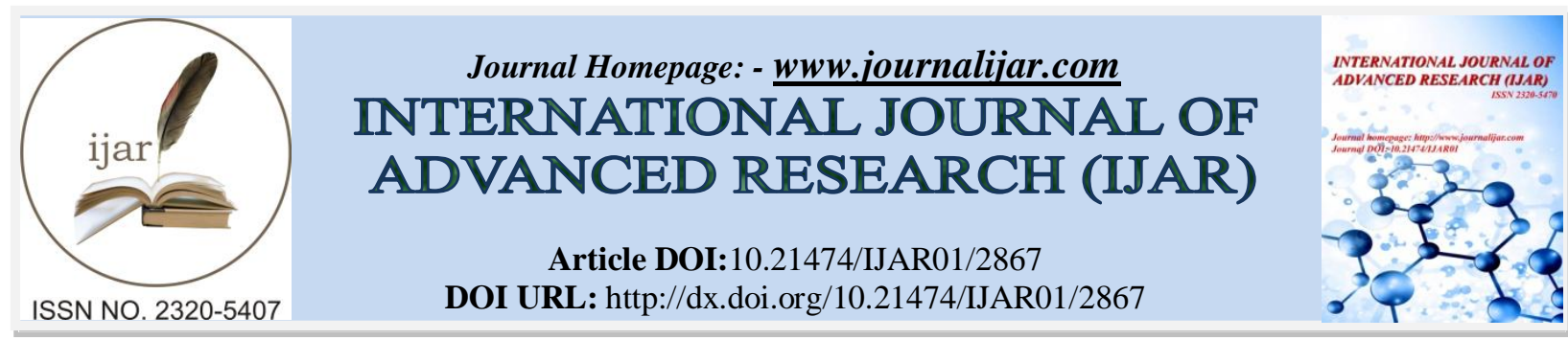

RESEARCH ARTICLE

\title{
AMELIORATIVE EFFECT OF THE AURELIA AURITACRUDE VENOM ON THE MURINE EHRLISH ASCITES CARCINOMA-INDUCED HEPATOTOXICITY AND NEPHROTOXICITY.
}

Sherifa H. Ahmed, Doaa M. Eissa, Mohamed K. Hassan and Osama A. Abaas. Zoology Department, Faculty of Science, Port Said University.

\section{Manuscript Info}

\section{Manuscript History}

Received: 21 November 2016

Final Accepted: 21 December 2016

Published: January 2017

Key words:-

Ehrlish ascites carcinoma - Aurelia aurita- hepatic and renal injury

\section{Abstract}

The ability of Jellyfish, Aurelia aurita(A.A)crude venom to modify the hepatic and renal dysfunction associated with Ehrlish ascites carcinoma (EAC) stress in experimental mice was assessed. Intraperitoneal injection of $A$.A. crude venom into EAC-bearing mice at different doses $(50,125,250,500,750 \mathrm{mg} / \mathrm{kg} \mathrm{B.W})$, daily, for 7 days was compared with the standard drug, cisplatin, $(2 \mathrm{mg} / \mathrm{kg})$. Loading the mice with EAC significantly reduced the red blood cells counts and subsequently reduced the hemoglobin (HB). Administration of $A$.A venom significantly restored red blood count and HB. EAC load had increased the activities of serum AST and ALT but decreased the concentration of albumin and total protein.

A.A. crude venom as well as cisplatinimproved the hepatic injury by declining the ALT activity and increasing albumin values but no significant changes in the total protein were observed. Moreover, levels of the renal biomarkers, creatinine and urea were highly elevated in EAC-bearing mice. Interestingly unlike cisplatin, levels of those renal biomarkers, creatinine and urea, were significantly decreased by A.A. crude venom administration. Furthermore, histopathological examinations revealed hepatic and renal tissues improvement in EAC-loaded mice after venom administration compared with control group. Taken together, results from thisstudy suggest that $A . A$ crude venom can potentially reduce the hepatic and renal damage induced by EAC load in experimental animals.

Copy Right, IJAR, 2016,. All rights reserved.

\section{Introduction:-}

Marine environment has always been considered as rich sources of both biological and chemical diversity. Marine organisms are the main sources of structurally diverse bioactive compounds. The great deal of interest has been expressed regarding marine derived bioactive peptides because of their numerous health related beneficial effects (Kim and Wijesekara, 2010).

Cnidarians venoms have roles in drug discovery as the toxic compounds isolated from cnidarian have been viewed to produce several serious implications to human health due to their neurotoxicity, cytotoxicity and tissue damage. Their toxins might offer a tool to study cell physiology (Morabitoet al., 2015) and provide promising sources of pharmacological agents for therapy of human diseases. 
Biological properties of venom from terrestrial animals have been extensively investigated, while scarce research has been undertaken jellyfish venom. Most of the proteinaceous venoms showing marked curative properties are from highly toxic species (snake, scorpion, etc) and their high toxicity hinders clinical trials. Hence, less toxic species like jellyfish represent a valuable source of pharmacological compounds that may lead compounds for new drugs.

In vitro toxic action of the venom from A.Ahas received some attention. Lethality and dermonecrosis were observed in mice, with variouspotencies depending on the origin of the specimen (Radwanet al., 2001). The venom is hemolytic to human, sheep, and bovine red blood cells (Radwanet al., 2001, Segura et al., 2002 and Rastogiet al., 2012). Protease and phospholipase A activities were recorded to change in response to such venom (Nevalainenet al., 2004and Lee et al., 2011).

Previous studies concluded that SDS-PAGE electrophoresis revealed that the crude venom of A.A contains several bands between 200 and $6 \mathrm{kDa}$ (Rastogiet al., 2012). The venom was purified by chromatography and the neurotoxic activity of some fractions was characterized. The protein fractions named Aa-1 and Aa- 2 were identified and used for further studies. After intramuscular injections with $0.06 \mathrm{mg}$ protein $/ \mathrm{kg}$ in $0.1 \mathrm{ml} / \mathrm{vol}$ of fractions Aa-1 or Aa-2, adult crabs developed tetanic reactions followed by total paralysis and death within three minutes. The molecular weights of Aa-1 and Aa-2 were 66 and 45 kDa, respectively (Segura et al., 2002 and Ponce et al., 2013).

Cancer is a group of diseases involving abnormal cell growth with the potential to invade or spread to other parts of the body and associated with different organs disorder. Cisplatin has become one of the most used drugs in the treatment of solid tumors of epithelial origin. Although cisplatin has been a mainstay for testicular cancer therapy (Einhorn, 1997), it is also commonly used to treat ovarian, cervical, bladder, and non-small cell lung carcinoma as well as head and neck cancers (Armstrong, 2006, Helm and States, 2009 and Konstantakou, 2009). The two limiting factors for a successful application of cisplatin are acquired or intrinsic drug resistance of the tumor and severe side effects in normal tissues, mainly in the kidney, in the inner ear and in the peripheral nerves (Pabla and Dong, 2008).

In this regard, the present study aimed to evaluate the potency of $A . A$ crude venom to improve the hematological, biochemical and histological injuries induced in the kidney and liver byEAC-loaded in the experimental mice and compare this effect, if there is any with this of cisplatin as one of anticancer drug.

\section{Material and Methods:-}

$A . A$ sampling areas:-

A.Awas collected during June, 2014 from the Red sea "Wadi el Gemal protected national park" from North head Hnkurab and North head Baghdadi areas.

\section{Venom preparation:-}

A.Acrude venom was prepared as described by Torres and Heimer, (2001) as follows; the oral arms and tentacles of organisms were clipped manually, combined and centrifuged at $1620 \mathrm{~g}$ for $10 \mathrm{~min}$ at $\left(4^{\circ} \mathrm{C}\right)$. The pellet was resuspended in distilled water, lyophilized and stored at $\left(-20^{\circ} \mathrm{C}\right)$. The nematocysts rupture was monitored optically in order to obtain their maximal discharge. The best technique for nematocysts discharge was obtained by applying an osmotic shock by resuspending freshly lyophilized samples in deionized water $(1 \mathrm{mg} / 10 \mu \mathrm{l})$, this preparation was stirred for two minutes and centrifuged at $1932 \mathrm{~g}$ for $30 \mathrm{~min}$ at $\left(4^{\circ} \mathrm{C}\right)$. The supernatant was then centrifuged at 11130 $\mathrm{g}$ for $20 \mathrm{~min}$ at $\left(4^{\circ} \mathrm{C}\right)$, and filtered $(0.45 \mu \mathrm{m})$. The venom isolated and resuspended in this form, maintained full activity when stored at $\left(-20^{\circ} \mathrm{C}\right)$ for 1 month.

\section{Expermintal animals:-}

One hundred twenty Swiss albino female mice were purchased from Faculty of Pharmacy Mansoura University. They were housed in plastic cages under standard condition of humidity, temperature, chow and water in the animal lab of Faculty of Science, Port Said University until became of suitable weight. EAC-bearing albino mice (tumor donor animals) were obtained from Tumor National institute, Cairo, Egypt. These mice were kept in the same conditions of normal mice. 
$1 \mathrm{ml}$ Ehrlish tumor cells were drawn and diluted with saline $(0.9 \% \mathrm{NaCl})$. Using haemocytometer, the tumer cells were counted and $0.2\left(1 \times 10^{7}\right) \mathrm{ml}$ of freshly drawn diluted ascites fluid were intraperitonealy injected into the normal experimental mice.

\section{Experimental design:-}

Animal grouping:-

After $72 \mathrm{~h}$ of Ehrlish tumor cell injection, Female mice were grouped as follows

1. Group1. Normal mice (Normal control)

a. $\quad$ Normal mice were I.P injected with $0.9 \%$ normal saline.

2. Group2. EAC-bearing mice (Positive control)

a. $\quad$ Normal mice were I.P injected with $0.2 \mathrm{ml}\left(1 \times 10^{7}\right)$ tumor cells/mouse.

3. Group3. EAC $+(50 \mathrm{mg} / \mathrm{kg} \mathrm{BW})$

4. Group4. EAC $+(125 \mathrm{mg} / \mathrm{kg} \mathrm{BW})$

5. Group5. EAC+ $(250 \mathrm{mg} / \mathrm{kg} \mathrm{BWy}$

6. Group6. EAC+ $(500 \mathrm{mg} / \mathrm{kg} \mathrm{BW})$

7. Group7. EAC+ $(750 \mathrm{mg} / \mathrm{kg}$ BW $)$

\section{A.A crude venom daily for 7 days}

8. Group8. EAC+cisplatin:Tumor-bearing mice after $72 \mathrm{~h}$ of tumor cell injection were I.P injected with the standard drug at dose $(2 \mathrm{mg} / \mathrm{kg})$ every day for 7 days as standard drug control (El-Nagar, 2011).

\section{Collection of samples:-}

The bloodsamples were collected from control group and treated groups after 7 days of daily treatment. Blood samples were collected in EDTA tubes for hematological analysis, another blood sample were left for clotting, centrifuged at $300 \mathrm{rpm}$ for 15 minutes and immediately frozen at $\left(-20^{\circ} \mathrm{c}\right)$ till the biochemical assay (ALT, AST, albumin, total protein, urea andcreatinine) were carried out. Kidney and liver of the normal, EAC-bearing albino mice and treated animals were fixed in formalin (10\%) for histopathological assay.

\section{Hematological and Biochemical assays:-}

Complete blood count (CBC) includes hemoglobin content, Red blood cells (RBC), white blood cells (WBC), and platelets (PT) counts. It was done by Abbott CELL-DYN1800 automated hematology analyzer, USA, using readymade kits produced by Abbott laboratories, Abbott Park, IL, 60064, USA. Serum biochemical analysis was determined by colorimetric methods using ready-made kits produced by Linear Chemicals. S.L. Biochemical, BIOMED, SPINERACT diagnostic assays include Aspartate transaminase (AST), Alanine transaminase (ALT), Albumin, Total protein, Urea and Creatinine.

\section{Statistical analysis:-}

Data was statistically analyzed using Minitab, using a MINITAB (Lenth, 1989). Tabulation and graphics of data were done using Microsoft Excel XP. All of the data of control and treated groups were expressed as mean values \pm standard error. One-way ANOVA and unpaired t-test were carried out to find if there was any significant difference among control and treated groups with A.A crude venom at different doses.

\section{Results:-}

\section{Haematological assay:-}

The alteration of hematological parameters induced in EAC-bearing albino mice and the protective effect of A.A crude venom are given in table (1) comparing to cisplatin post treatment.

As shown in Table (1) EAC-bearing albino mice had a significant decline in $\mathrm{Hb}$, Red blood cells but non-significant changeof White blood cell, and platelet counts when compared with control group. Administration of different doses of $A . A$ crude venom after injection with EAC had significantly increased $\mathrm{Hb}$, Red blood cell. While nonsignificant changes were observed on the $\mathrm{Hb}$ levels in the groups administered with doses 125, 250, 500 and 750 $\mathrm{mg} / \mathrm{kg}$ BW of $A$.Acrude venom. Adminstration of the standard drug, cisplatin, at dose of $2 \mathrm{mg} / \mathrm{kg}$, showed nonsignificant changes in hemoglobin levels and significant elevatation in the RBCscount when compared with the EAC control group. 
Table 1:- Effect of A.Acrude venom and $(2 \mathrm{mg} / \mathrm{Kg} \mathrm{BW})$ Cisplatinon hematological parameters of EAC-bearing Swiss albino female mice.

\begin{tabular}{|c|c|c|c|c|}
\hline$\underbrace{\text { Parameter }}_{\text {Groups }}$ & $\begin{array}{l}\text { Haemoglobin } \\
\text { (g/dL) }\end{array}$ & $\begin{array}{c}\text { RBCs count } \\
\left(\times 10^{6} / \mu \mathrm{L}\right)\end{array}$ & $\begin{array}{c}\text { WBCs count } \\
\left(\times 10^{3} / \mu \mathrm{L}\right)\end{array}$ & $\begin{array}{l}\text { Platelets count } \\
\left(\times 10^{3} / \mu \mathrm{L}\right)\end{array}$ \\
\hline Normal control & $9.58 \pm 0.258$ & $5.212 \pm 0.104$ & $8.02 \pm 0.229$ & $194.4 \pm 17.608$ \\
\hline EAC control & $7.26 \pm 0.597^{b^{* * *}}$ & $2.8 \pm 0.10^{\mathbf{b}^{* * * *}}$ & $6.5 \pm 0.776$ & $115.8 \pm 1.907$ \\
\hline $\begin{array}{c}\text { EAC + Cisplatin } \\
(2 \mathrm{mg} / \mathrm{Kg} \mathrm{BW})\end{array}$ & $6.98 \pm 0.427$ & $2.24 \pm 0.051^{\mathrm{a}^{* * * * 6}}$ & $8.06 \pm 0.112$ & $97.2 \pm 2.956^{\mathbf{a}^{* * *}}$ \\
\hline $\begin{array}{c}\mathrm{EAC}+50 \mathrm{mg} / \mathrm{kg} A . A \\
\text { venom }\end{array}$ & $9.18 \pm 0.262^{\mathrm{a}^{*}}$ & $5.08 \pm 0.454^{\mathrm{a}^{\mathrm{a} * * *}}$ & $7.86 \pm 0.384$ & $118 \pm 4.898$ \\
\hline $\begin{array}{c}\mathrm{EAC}+125 \mathrm{mg} / \mathrm{kg} A . A \\
\text { venom }\end{array}$ & $8.5 \pm 0.519$ & $4.854 \pm 0.613^{\mathrm{a}^{* * *}}$ & $9.62 \pm 0.220^{\mathrm{a}^{* *}}$ & $150.2 \pm 3.942^{\mathrm{a}^{* * * *}}$ \\
\hline $\begin{array}{c}\mathrm{EAC}+250 \mathrm{mg} / \mathrm{kg} A . A \\
\text { venom }\end{array}$ & $8.34 \pm 0.627$ & $5.03 \pm 0.638^{\mathrm{a}^{* * * *}}$ & $10.04 \pm 0.549^{\mathrm{a}^{* * *}}$ & $170.4 \pm 17.823^{\mathrm{a}^{* * *}}$ \\
\hline $\begin{array}{c}\mathrm{EAC}+500 \mathrm{mg} / \mathrm{kg} A . A \\
\text { venom }\end{array}$ & $9.08 \pm 0.600$ & $5.09 \pm 0.286^{\mathbf{a}^{* * * *}}$ & $9.78 \pm 0.950^{\mathrm{a}^{*}}$ & $174.2 \pm 20.582^{\mathrm{a}^{*}}$ \\
\hline $\begin{array}{c}\mathrm{EAC}+750 \mathrm{mg} / \mathrm{kg} A . A \\
\text { venom }\end{array}$ & $8.58 \pm 0.888$ & $4.97 \pm 0.595^{\mathrm{a}^{* * *}}$ & $8.52 \pm 1.047$ & $194.8 \pm 10.767^{\mathbf{a}^{* * * * *}}$ \\
\hline ANOVA(Pvalue) & & 0.000 & 0.005 & 0.000 \\
\hline
\end{tabular}

Results expressed as Mean \pm SE ( $\mathrm{n}=5$ ). ANOVA (P value) represents the difference between all groups. ${ }^{\mathrm{a}}$ represents significantly different comparing with EAC control group. ${ }^{\mathbf{b}}$ represents significantly different comparing with normal control group. $*(\mathrm{p}<0.05), * *(\mathrm{p}<0.01), * * *(\mathrm{p}<0.001)$.

\section{Biochemical Assay:-}

a-Hepatic biomarkers:-

The changes in the serum liver biomarkers are shown represented in Figure 1(A, B. C, D).

EAC load in albino mice induced hepatotoxicity which is represented as significant increase in liver biomarkers; serum AST and ALT activities $(\mathrm{P} \leq 0.01 \& \mathrm{P} \leq 0.05)$ respectively. Both treatments with different doses of A.Acrude venom at all doses $50,125,250,500$ and $750 \mathrm{mg} / \mathrm{kg} \mathrm{BW}$ and the standard drug, cisplatin, non-significantly changed AST activities while different doses of A.Acrude venom at all doses 50, 125, 250, 500 and $750 \mathrm{mg} / \mathrm{kg} \mathrm{BW}$ and the standard drug, cisplatin, significantly declined ALT activities and ameliorate the hepatotoxicity induced by EAC as noticed in Fig 1-A and B

Moreover, Serum albumin, total protein were highly significant decreased $(\mathrm{P} \leq 0.001)$ in EAC-bearing albino mice. I.P treatment of EACs-bearing mice with A.A crude venom induced significant increase $(\mathrm{P} \leq 0.05)$ in albumin levels at dose 50,125 and $250 \mathrm{mg} / \mathrm{kg} \mathrm{BW}$ and non-significant changes at higher doses 500 and $750 \mathrm{mg} / \mathrm{kg}$. Similarly, the standard drug, cisplatin, induced a very highly significant increase $(\mathrm{P} \leq 0.001 ;$ Fig $1 \mathrm{C})$

I.P treatment of EACs-bearing mice with different doses of A.A crudevenom induced non-significant changes in the serum total protein content at low doses 50, 125 and $250 \mathrm{mg} / \mathrm{kg}$ BW. Meanwhile, high doses 500 and $750 \mathrm{mg} / \mathrm{kg}$ BW of $A . A$ crudevenom caused very highly significant decrease $(\mathrm{P} \leq 0.001$ and $\mathrm{P} \leq 0.01)$. Treating EAC-control mice with the standard drug, cisplatin, induced non-significant changes as shown infig1D. 


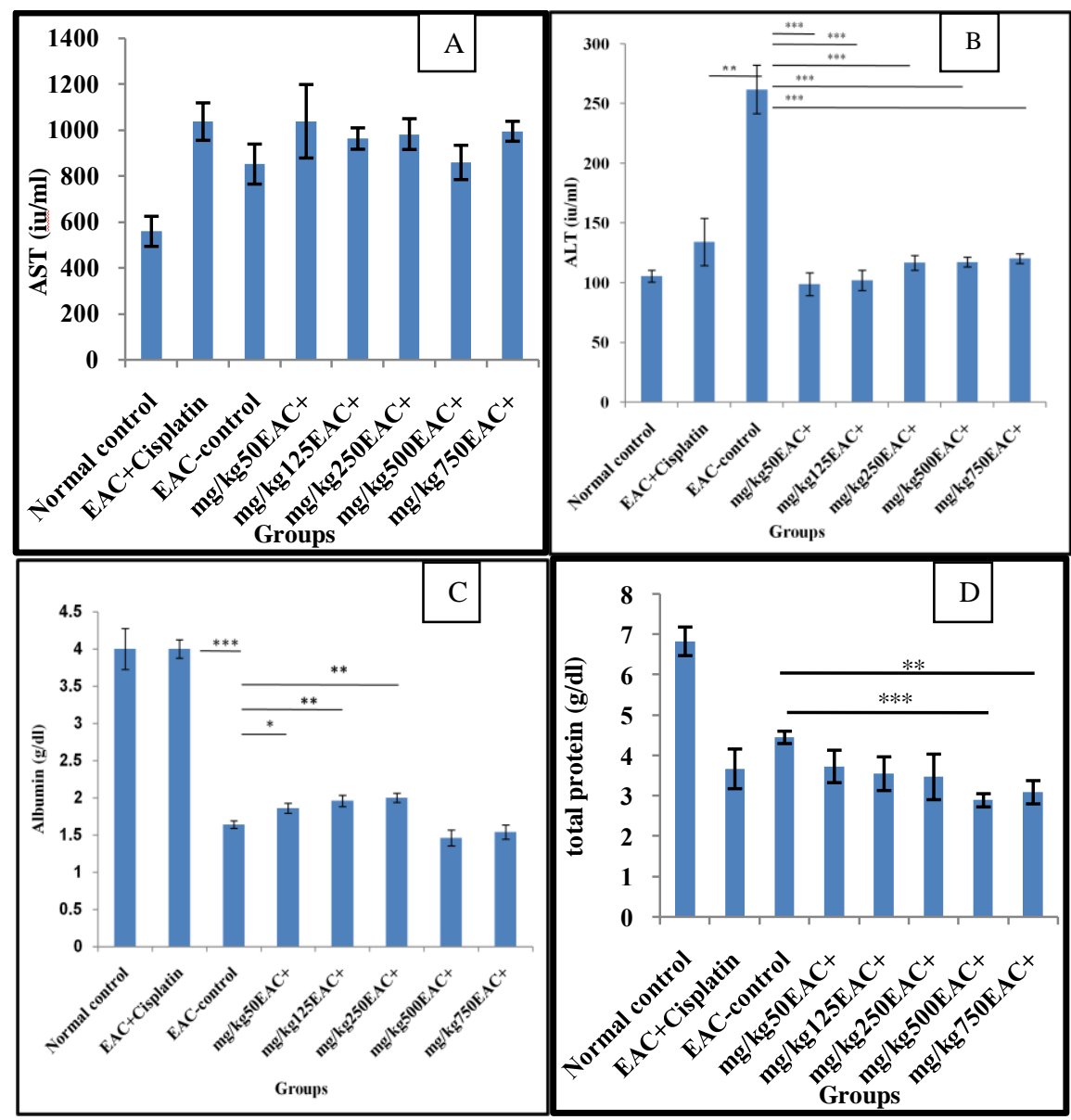

Figure 1:- Effect of A.A crude venom on the alteration of biochemical markers induced by EACs-bearing mice, (A) AST, (B) ALT, (C) albumin and (D) total protein levels. * $(\mathrm{p}<0.05), * *(\mathrm{p}<0.01), * * *(\mathrm{p}<0.001)$.

\section{Renal Biomarkers:-}

EAC-bearing albino mice induced renal damage which is represented as disturbance in renal biomarkers (creatinine and urea). As shown in Fig 2, urea had non-significantly changed $(\mathrm{P} \leq 0.001)$, while creatinine was significantly increased in EAC-bearing albino compared to those of the normal mice.

Treatment of EACs-bearing mice with different doses of A.A. crude venom caused a significant decline in serum urea and creatinine at all doses 50,125, 250, 500 and $750 \mathrm{mg} / \mathrm{kg} \mathrm{BW}$ respectively. On the other hand, EAC-control mice treatment with cisplatin did not induce any noticeable changes in urea concentration but caused a significant increase $(\mathrm{P} \leq 0.01)$ in creatinine, as illustrated in figure $\mathbf{2 A , B}$. 

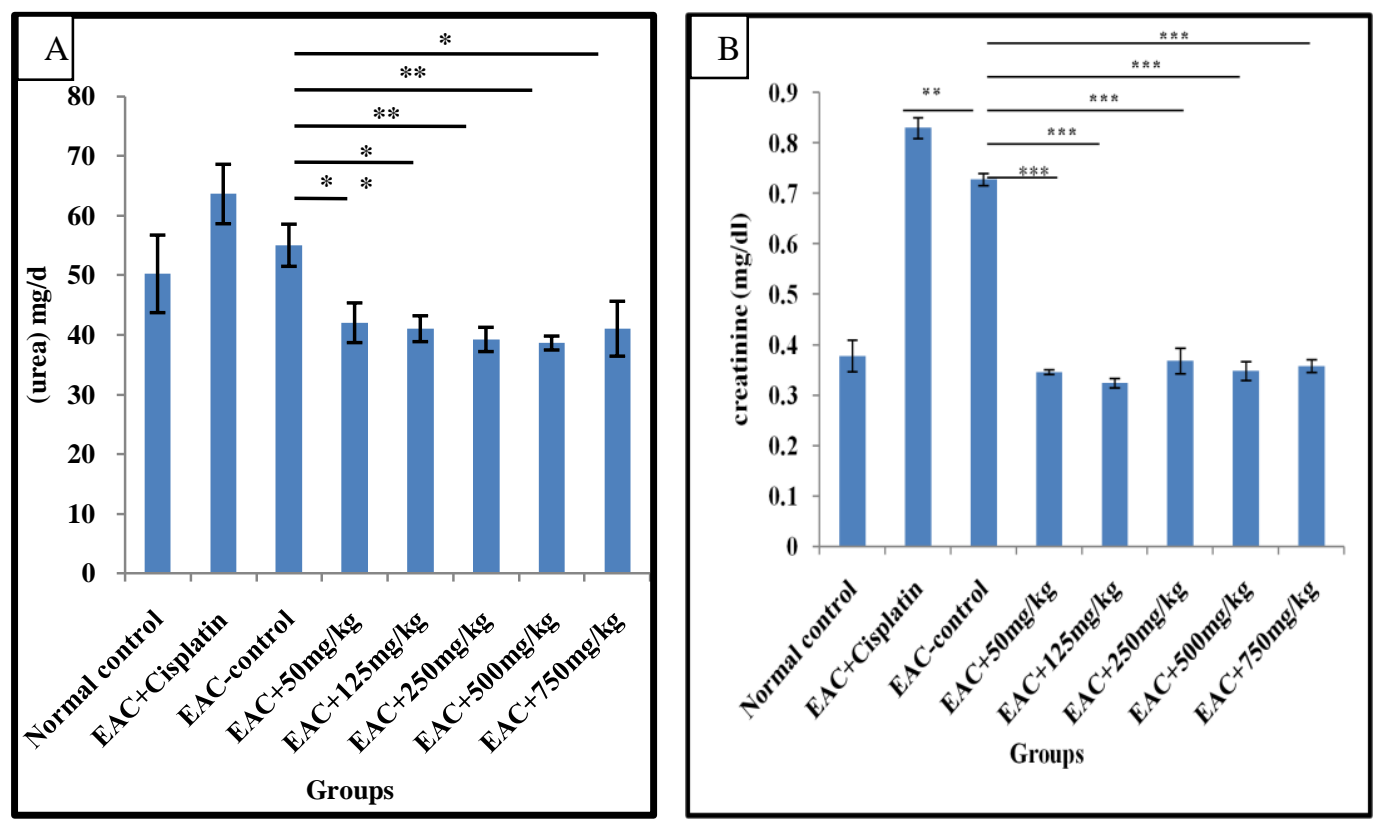

Figure 2:- Effect of A.A crude venom on the alteration of biochemical markers induced by EACs-bearing mice. urea $(\mathrm{A})$, creatinine $(\mathrm{B}), *(\mathrm{p}<0.05), * *(\mathrm{p}<0.01), * * *(\mathrm{p}<0.001)$.

\section{HistopathologicalAssay:-}

Liver and kidney from EAC-loaded mice, A.A crude venom-treated EAC-bearing mice and cisplatin treated EACbearing mice were represented in Fig 2 and 4. As shown loading mice by EAC deteriorate lobular architecture where hepatocytes showed enlarged nuclei, hydropic degeneration and sinusoidal infiltration of carcinoma cells mixed with lymphocytes. In addition, marked degenerative changes of renal tubules, stromal congestion and moderate inflammation with mild degeneration of glomeruli, an improvement in hepatic and renal tissues in EAC-loaded mice after $A$.A crude venom administration was observed at figures $3(\mathbf{A}-\mathbf{H})$. 

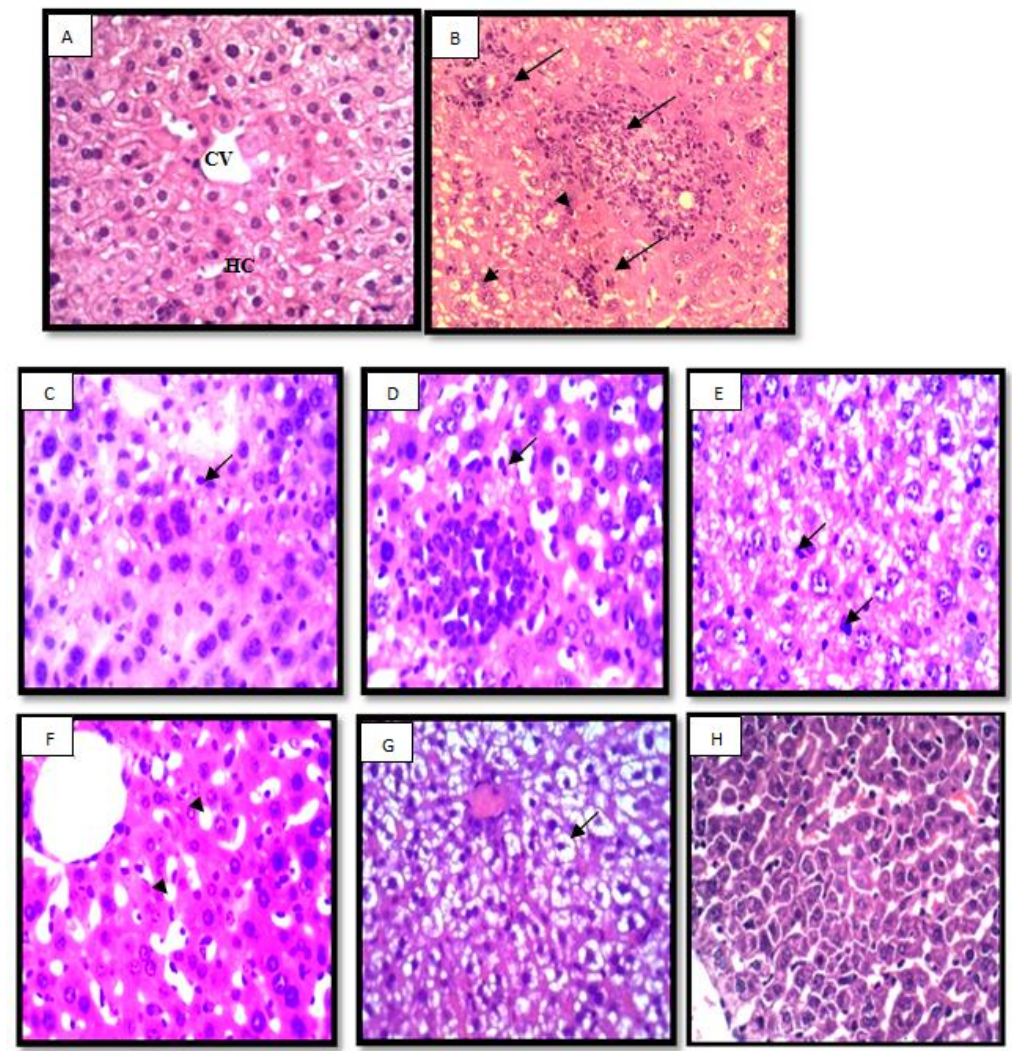

Figure 3:- Histopathology of liver in normal and EAC-bearing mice groups. A- Section of liver of normal control mice showing normal histological appearance of liver including central vein (CV), hepatic cells (HC). B- Section of liver of EAC-bearing mice illustrating hydropic degeneration (arrow head) and sinusoidal infiltration of carcinoma cells mixed with lymphocytes (arrows). C- Section of liver of $\mathbf{5 0} \mathrm{mg} / \mathrm{kg} \mathrm{BW}$ A.A. venom-treated EAC-bearing mice showing shrunken deeply stained nuclei (arrow). D- Section of liver of $\mathbf{1 2 5} \mathrm{mg} / \mathrm{kg}$ BW A. A. venom-treated EACbearing mice showing shrunken deeply stained nuclei (arrow) E- Section of liver of $\mathbf{2 5 0} \mathrm{mg} / \mathrm{kg}$ BW A.A. venomtreated EAC-bearing mice showing restored normal lobular architecture, still to notice very few hepatocytes showed shrunken deeply stained nuclei (arrow). F- Section of liver of $\mathbf{5 0 0} \mathrm{mg} / \mathrm{kg} \mathrm{BW}$ A.A. venom-treated EAC-bearing mice showing mild improvement with hydropic degenerative changes (arrow head). G- Section of liver of $750 \mathrm{mg} / \mathrm{kg} \mathrm{BW}$ A.A. venom-treated EAC-bearing mice showing: marked improvement with mild degenerative changes (arrow). HSection of liver of $2 \mathrm{mg} / \mathrm{kg}$ BW cisplatin-treated EAC-bearing mice illustrating some hepatocytes hydropic degeneration and ballooning degeneration (arrow head). Slides captured with Power Field of 400x 

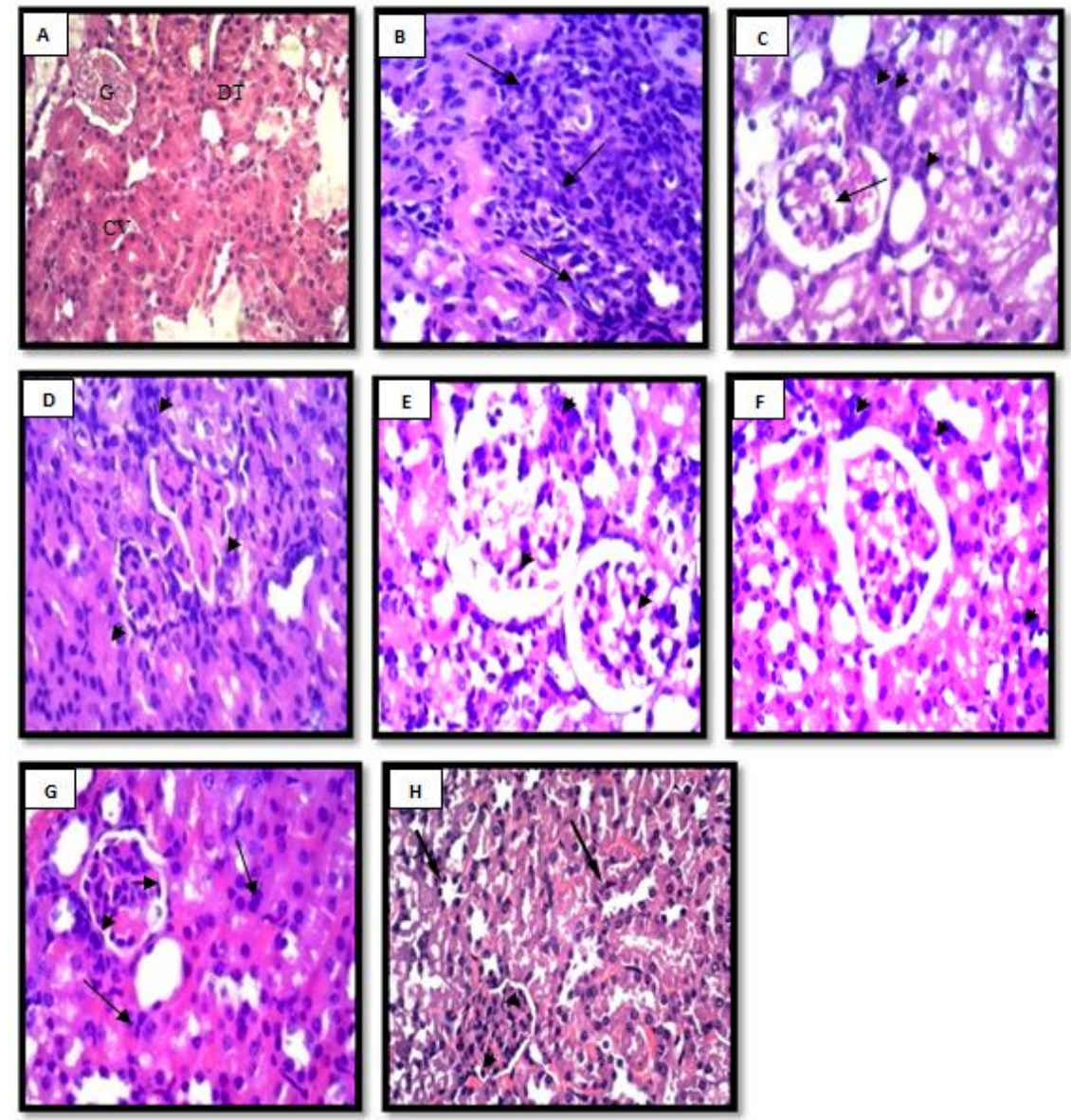

Figure 4:- Histopathology of kidney in normal, EAC-bearing and treated EAC-bearing mice groups. A- section of the cortical tissue of the kidney of control normal mice showing glomeruli(G), proximal and distal convoluted tubules (DT) B- Section of mice kidney of EAC-control group showing moderate inflammation with mild degeneration of glomeruli, accompany the infiltration of many proliferating groups of neoplastic cells (arrow). CSection of mice kidney of $\mathbf{5 0} \mathrm{mg} / \mathrm{kg}$ BW A.A. venom-treated EAC-bearing mice. D- Section of mice kidney of $\mathbf{1 2 5}$ $\mathrm{mg} / \mathrm{kg}$ BW A.A. venom-treated EAC-bearing mice illustrating degenerative changes of tubules and inflammation with mild degeneration of glomeruli (arrow) Neoplastic cells are fewer than EAC control denoting minimal improvement (arrow head) E- Section of mice kidney of $\mathbf{2 5 0} \mathrm{mg} / \mathrm{kg}$ BW A.A. venom-treated EAC-bearing mice showing cortical tissue few of neoplastic proliferation with minimal glomerular capillary congestion (arrow head). F- Section of mice kidney of $\mathbf{5 0 0} \mathrm{mg} / \mathrm{kg}$ BW A.A. venom-treated EAC-bearing mice showing fewer neoplastic cells are than EAC control denoting minimal improvement (arrow head). G- Section of kidney of $\mathbf{7 5 0} \mathrm{mg} / \mathrm{kg} \mathrm{BW} \mathrm{A.A.}$ venom-treated EAC-bearing mice showing kidney totally free of neoplastic proliferation with minimal glomerular capillary congestion (arrow head) and mildly degenerated tubules (arrow). H- Section of kidney of $2 \mathrm{mg} / \mathrm{kg} \mathrm{BW}$ cisplatin-treated EAC-bearing mice showing degeneration of tubes and congestion of corpuscles (arrowhead) and mildly degenerated tubules (arrow). Slides captured with high Power Field (HPF) of 400x.

\section{Discussion:-}

Several marine organisms are of considerable interest as a new promising antitumor source. The present investigation showed the ability of $A . A$ crude venom at different doses $50,125,250,500$ and $750 \mathrm{mg} / \mathrm{kg} \mathrm{BW}$ to restore the hematological, biochemical, histopathological disorders developed in experimental mice bearing EAC cells.

The current study revealed that anemia is associated with loading the mice with EAC. It was reported that anemia encountered in tumor bearing mice is mainly due to reduction in RBC and/or hemoglobin percentage and this may occur either due to iron deficiency or due to hemolytic or myelopathic conditions (Fenninger and Mider, 1954 and Sinclair, et al., 1990). 
In the current study, hemoglobin content, RBCs count and platelets count showed significant decrease in EACbearing control mice. Interestingly, treatment with $A . A$ crudevenom with different doses induced appreciated increase in hemoglobin, RBC, WBCs and platelets counts after venom injection. The increase in RBCS, hemoglobin and platelets after treated with A.A crudevenom are running in agreement with the data by Zaki, (2005) who proved the antitumor effect of sea cucumber, Holothuriaatra, crude venom on biochemical and hematological parameters on rat, and suggested that this increase in the in RBCS, hemoglobin and platelets may be attributed to activation of the bone marrow by sea cucumber. Similarly, this explanation runs in agreement with Jakowskaet al., (1958) who reported that the toxin of sea cucumber stimulates hemopoiesis in the bone marrow.

The increase in hemoglobin levels, RBCs, WBCs and platelets counts indicates that $A . A$ crude venom may possesses a protective action for the hematopoietic system. On the other hand, the significant increase in WBC's may result from the stress induced by venom injection as reported by Bawaskar, (2012) who studied the effect of scorpion sting.

The fact that haemoglobin and RBC content are increased in A.A crude venom-treated groups is consistent with the result by Meenakshi, et al., (2013) and this result by Abd El-Aziz et al., (2014) who studied the inhibitory effects of Rosemary (Rosmarinusofficinalis L.) on EAC-bearing mice. Similar effect was observed by Gupta et al., (2004) for the extract of Bauhinia racemosa stem bark on EAC bearing mice. Moreover the increase in platelets count might be due to platelets activation according to Konca et al., (2014) who reported that during his study on the platelet function in children with scorpion envenomation.

In cancer chemotherapy, the major problems are myelo suppression and anemia (Price and Greenfield, 1954). In the present study, the treatment of EAC-bearing mice with the standard drug, cisplatin induced significant decrease in RBCs, hemoglobin and platelets levels comparing with EAC-control mice. Based on these results, A.Acrude venom may has an advantage to restore the haematological parameters which distorted by cancer in EAC-bearing mice model.

Hepatic enzymes including ALT and AST showed a significant elevation in the EAC control group in comparison with normal control which indicates the hepatocellular damages caused by inoculation with EACs (El-Dayemet al., 2013). Moreover, our results revealed that the levels of hepatic enzymes (ALT, AST) were elevated in the EACbearing mice. Administration of A.A crude venom to EAC-bearing mice reduced the elevated ALT level indicating a recovery from EAC hepatotoxicity. Reduced level of this hepatic enzyme in serum is one of the indications of the antitumour potential (Chakrabortyet al., 2006 andSundaramet al., 2012).

The current study demonstrated that the treated mice with different doses of A.A crude venom can elevate the plasma level of AST; this might be due to hepatocellular toxicity. Treatment with cisplatin as a standard drug elevated transaminases values indicating a hepatic toxicity too.

In support of this finding, elevation in the plasma levels of AST also agrees with the data by Liang et al (2011) who studied the effects of tentacle-only extract from the jellyfish Cyaneacapillatasp and the results by Bruschetta et al., (2014) who studied the inflammation and oxidative stress by the crude venom extracted from the jellyfish Pelagianoctiluca in rats.

Abu-Amraet al. (2015) studied the role of bradykinin potentiating factor (BPF7) separated from jellyfish, Cassiopiaandromeda. It was suggested that the marked increase in this hepatic enzyme by this factor may be due to an enhancement of protein biosynthesis, changes of cellular permeability and release of cyclic AMP. This suggestion was also recommended by Enjalbertet al., (1980), Etgen and Browning, (1983), Abu-Amra and Abd El-Rehim, (1992) and Abu-Amra (2000).

On the other hand, the biochemical results of EAC-bearing mice revealed a decrease in the albumin and total protein levels; this may be attributed to increased mitotic division of tumor cells with high body fluid withdrawal and the capillary permeability, which permit the escape of plasma proteins into peritoneal cavity (Garrison et al., 1987).

Furthermore, hypoproteinemia and hypoalbuminemia may be due to excessive nephritis and/or massive ascites and also associated with liver disease. This is in parallel to increased AST activity which may be attributed to hepatic damage as a result of cancer cells invasion (Badret al., 2011). Treatment of EAC-bearing 
mice with A.A crude venom had significantly increased albumin level in a dose-dependent pattern in lower doses $(50,125$ and $250 \mathrm{mg} / \mathrm{kg} \mathrm{BW})$ and return to decrease albumin level non-significantly in the higher doses (500 and $750 \mathrm{mg} / \mathrm{kg} \mathrm{BW}$ ), while treatment with cisplatin elevated albumin value to be restored to normal values.

This change of albumin levels recorded in the A.A crude venom-treated animals is in agreement with Abd El-Aziz et al., (2014). The decrease in albumin level in Ehrlich group and its improvement by A.A crude venom may be due to A.Ahepatoprotective activity in EAC-bearing-treated mice. In line with these findings, Natesanet al., (2007) and Senthilkumaret al., (2008) showed that the methanol extract of Careyaarborea (has antitumor effect) have a hepatoprotective activity in EAC-bearing mice.

In the present study we found a decrease in total protein level after the administration of $A . A$ crude venom. The same effect was observed in the cisplatin-treated EAC-bearing mice. This decrease in total protein level after the administration of A.A crude venom agrees with the study by Zaki, et al., (2005). This decrease may be due to increased catabolism of plasma proteins, or to impaired synthesis of the protein.

It was demonstrated that, the presence of tumors in human body or experimental animals is known to affect many functions of vital organs (DeWys, 1982). At the current study, urea and creatinine levels, which are considered as makers of kidney function, were significantly elevated in serum of EAC-control mice indicating renal impairment. These alterations induced by toxic conditions, reflected metabolic cellular dysfunction of these tissues (Robbins et al., 2001). An elevation of urea may be attributed to an increase in nitrogen retention or excessive protein breakdown (Geraciet al., 1990).

Treatment with A.A crude venom gradually returned the increased levels of urea and creatinine to more or less the normal values, while the treatment of EAC-bearing mice with cisplatin maintained their higher values.

Histopathological assay offered more evidence for improving the EAC-induced cytotoxicity by A.A crude venom. Treatment with different doses of $A . A$ crude venom especially high doses showed regular hepatocytes with abundant cytoplasm with mild hydropic degeneration and mild degenerative changes similar to control.

In addition, treating EAC-bearing mice with the $A . A$ crude venom especially, at the highest doses shows kidney totally free of neoplastic proliferation with minimal glomerular capillary congestion and mildly degenerated tubules with interstitial inflammation. This result is similar to that reported by Nagarjunaet al., (2013) when they studied the anti-cancer activity of Ruelliatuberosa on EAC induced mammary tumor.

In conclusion, loading mice with EAC-bearing mic- induced haematological, hepatic and renal toxicity. I.P administration of $A . A$ crude venom could restore the hepatic and renal biomarkers which were disturbed by EAC application, moreover, A.A crude venom had improved the histopathological disturbances by EAC load. This biological activities induced by A.A crude venom might be attributed to some bio-active compounds. Further researches are still required to separate and identify the biologically active protein of $A$.A crude venom individually, then determined the biological mechanism of the effective fraction/s.

\section{References:-}

1. Abd El-Aziz, M.E.Hefni and Amira M. Shalaby (2014): Inhibitory effects of Rosemary (Rosmarinusofficinalis L.) on Ehrlich ascites carcinoma in mice. Int.J.Curr.Res.Aca.Rev.2014; 2(9):330-357 .

2. Abu-Amra S. (2000): Physiological studies on diabetic male albino mice treated with bradykinin potentiating factor (BPF 7) separated from jellyfish and cobra snake venoms. J. Egypt Ger. Soc. Zool., 31(A): 211-233 .

3. Abu-AmraS., and Abd El-Rehim S.A (1992): Effect of factors isolated from venom of Egyptian snakes on plasma cholesterol, creatine kinase and alkaline phosphatase. J. Egypt. Ger. Soc. Zool., 9(A):75-89

4. Abu-Amra E., Abd-EL-Rehim S.A., Lashein F.M and Seleem A.A (2015): Influence of Bradykinin potentiating factor on protecting liver and kidney against the toxicity of indomethacin in male mice. Issue 5 1.625 .

5. Armstrong D.K (2006): I.P cisplatin and paclitaxel in ovarian cancer.NEngl J Med 354, 34-43.

6. Badre, S. (2014): Bioactive toxins from stinging jellyfish, Toxicon.09.010.

7. Bawaskar, H. (2012): Scorpion Sting: Update. J Assoc Physicians India 60,46-53. 
8. Bruschetta G., Impellizzeri D., Morabito R, Marino A., Ahmad A., Spanò N., La Spada G., Cuzzocrea S. and Esposito E. (2014): Pelagianoctiluca (Scyphozoa) Crude Venom Injection Elicits Oxidative Stress and Inflammatory Response in Rats. Mar Drugs, 12, 2182-2204.

9. Chakraborty T, Chatterjee A, Saralaya M.G and Chatterjee M., (2006): Chemopreventive effect of vanadium in a rodent model of chemical hepatocarcinogenesis: reflectionsin oxidative DNA damage, energydispersive X-ray fluorescence profile and metallothionein expression. J. Biol. Inorg. Chem. 11(7): 855-866.

10. DeWys W.D (1982): Pathophysiology of cancer cachexia: current understanding and areas for future research. Cancer Res. 42(2):721s.

11. El-Dayem S.M, Fouda F.M, Ali E.H and Motelp B.A (2013): The antitumor effects of tetrodotoxin and/or doxorubicin on Ehrlich ascites carcinoma bearing female mice. Toxicol Indus health, 29, 404417.

12. El-Naggar S.A (2011): Lack of the beneficial effects of Mirazied (commiphoramolma) when administered with chemotherapeutic agents on Ehrlich a scetic carcinoma bearing mice. AdvBiol Ress, 193-199

13. Einhorn E.H (1997): Testicular cancer: an oncological success story. Clin Cancer Res 3, 2630-2632.

14. Enjalbert A, Arancibia S, Ruberg M, Priam M, Bluet-Pajot M.T, Rotsztein W.H and Kordon C (1980): Stimulation of in vitro prolactin release by vasoactive intestinal peptide. Neuroendocrinology, 31:200-204 .

15. Etgen A.M and Browning E.T (1983): Activators of cyclic adenosine 3':5- monophosphate accumulation in rat hypocampal slices: Action of vasoactive intestinal peptide (VIP). J. Neurosci., 3(12): 2487-2493.

16. Fenninger L.D and Mider G.B (1954): Advances in cancer research. Grenstein JP, Haddow A, editors. v2. New York: Academic Press; 1954. p244.

17. Garrison R.K, Galloway R.H and Heuser L.S (1987): Mechanism of malignant ascites production. J Surg Res 42, 126-132.

18. Geraci J.P, Jackson K.L, Mariano M.S and Michieli B.M (1990): Kidney and lung injury in irradiated rats protected from acute death by partial -body shielding. Rad. Res., 112(1), 95 .

19. Gupta M, Mazumder U.K, Kumar R.S and Kumar T.S (2004): Antitumor activity and antioxident role of Bauhinia racemosa against Ehrlich ascites carcinoma in Swiss albino mice. ActaPharmacol Sin 25:1070-1076.

20. Helm C.W and States J.C (2009): Enhancing the efficacy of cisplatin in ovarian cancer treatment could arsenic have a role. J Ovarian Res 2, 2.

21. Jakowska S.R.F, Nigrelli R.F, Murray P.M and Veltri A (1958): Hemopoietic effects of Holothurin, a steroid saponin from the sea cucumber, Actinopygaagassizi, in Ranapipiens. Anat. Res., 132: 456-466.

22. Kim SK and Wijesekara I (2010): Development and biological activities of marine derived bioactive peptides: a review. J. Functional Foods., 2(1): 1-9.

23. Konca C, Tekin M, Colak P, Uckardes F, Turgut M (2014): An overview of platelet indices for evaluating platelet function in children with scorpion envenomation. ExpClinSci 67, 801-808.

24. Konstantakou E.G (2009): Human bladder cancer cells undergo cisplatin-induced apoptosis that is associated with p53-dependent and p53-independent responses. Int J Oncol 35, 401-416.

25. Lee H, Jung E, Kang C, Yoon W.D, Kim J.S and KimE (2011): Scyphozoan jellyfish venom metalloproteinases and their role in the cytotoxicity. Toxicon 58, 277e284.

26. Lenth R.V (1989): Quick and Easy Analysis of Unreplicated Factorials. Technometrics, Vol31, p.469.

27. Liang X., Sihua Liu, Qian He, Qianqian Wang, Xuting Ye, Guoyan Liu, FeiNie, Jie Zhao, and Liming Zhang (2011): The Acute Toxicity and Hematological Characterization of the effects of Tentacle-Only Extract from the Jellyfish Cyaneacapillata. Mar. Drugs, 9, 526-534

28. Meenakshi S., Paripoorana S., Gomathy S. and Chamundeswari (2013): In vitro and in vivo antitumor and immunomodulatory studies of Microcosmusexasperatus against DLA bearing mice. European Journal of Applied Engineering and Scientific Research, 2 (3):18-25.

29. Morabito R, La Spada G, Crupi R, Esposito E and Marino A (2015): Crude Venom from Nematocysts of the Jellyfish Pelagianoctiluca as a Tool to Study Cell Physiology. Cent. Nerv. Syst. Agents. Med. Chem., 15, 6873.

30. Nagarjuna Reddy, Nagarathna P.K.M and M Divya (2013): Evaluation of anti-cancer activity of Ruelliatuberosa on EAC induced mammary tumor International Journal of Pharmacology and Toxicology, 1 (2) 36-42

31. Natesan S, Badami S, Dongre S.H and Godavarthi A (2007): Antitumor activity and antioxidant status of the methanol extract of Careyaarborea bark against Dalton's lymphoma ascites induced ascitic and solid tumor in mice. J PharmacolSci 103:12-23.

32. Nevalainen T.J, Peuravuori H.J, Quinn R.J, Llewellyn L.E, Benzie J.A.H, Fenner P.J and Winkel K.D (2004): Phospholipase A2 in Cnidaria. Comp. Biochem. Physiol. B Biochem. Mol. Biol. 139, 731e735 
33. Pabla N. and Dong $\mathbf{Z}$ (2008): Cisplatin nephrotoxicity: mechanisms and renoprotective strategies. Kidney Int 73, 994-1007.

34. Price V.E and R.E Greenfeild (1954): Anemia in cancer. In: Advanced in Cancer Research. Greenstein J.P. and A. Haddow (Eds), New York: Academic Press, pp: 244.

35. Radwan F.F, Burnett J.W, Bloom D.A, Coliano T, Eldefrawi M.E, Erderly H, Aurelian L, Torres M and Heimer-de la Cotera E.P (2001):A comparison of the toxinological characteristics of two Cassiopea and Aurelia species. Toxicon 39, 245-257.

36. Rastogi A, Biswas S, Sarkar A and Chakrabarty D (2012): Anticoagulant activity of Moon jellyfish (Aurelia aurita) tentacle extract. Toxicon 60, 719-723.

37. Senthilkumar N, Badami S, Dongre S.H and Bhojraj S (2008): Antioxidant and hepatoprotective activity of the methanol extract of Careyaarborea bark in Ehrlich ascites carcinoma bearing mice. J. Ethnopharmacol. 116(1), 1-6.

38. Sinclair A.J, A.H Barnett and J Luine (1990): Free radical and autooxidant system in health and disease. Br. Hosp. Med., 43: 334-344.

39. Sundaram M, Patra S and Maniarasu G (2012): Antitumor activity of ethanol extract of Gracilariaedulis (Gmelin) Silva on Ehrlich ascites carcinoma- bearing mice. Journal of Chinese Intrgrative Medicine, 10 (4): 430-435

40. Ponce D, Lopez-Vera E, Aguilar M.B and Sanchez-Rodríguez J (2013): Pre-liminary results of the in Vivo and in Vitro characterization of a tentacle venom fraction from the jellyfish Aurelia aurita. Toxins 5, 2420-2433

41. Segura-Puertas L, Avila-Soria G, Sanchez-Rodríguez J, Ramos Aguilar M.E and Burnett J.W (2002): Some toxinological aspects of Aurelia aurita (Linne) from the Mexican Caribbean. J. Venom. Anim.Toxins8, 269-282.

42. Torres $\mathbf{M}$ and Heimer $\mathbf{E}$ (2001): A comparison of the toxinological characteristics of two Cassiopea and Aurelia species. Toxicon 39, 245-257.

43. Zaki M.A (2005): Effects of the crude toxin of sea CocumbersHolothuriaatra on some hematological and biochemical parameters in rats. Egyptian Journal of Natural Toxins, Vol. 2, 71-86. 